\title{
The 'Market' in the Theory of Regulation
}

\section{David Campbell}

Lancaster University School of Law, UK

market socialism has been struck off the agenda [but] a humane social market economy is the only sort of free economy likely to survive in the years to come, and the only sort that deserves to survive.

John Gray, The Moral Foundations of Market Institutions (1992: 123).

\section{Note by courtesy of the Editorial Board}

I was honoured to be asked to write, with Sol Picciotto, a paper on 'Regulation' which would be considered for the recent special issue of Social and Legal Studies commemorating the journal's 25th anniversary. The paper I drafted did not meet the reasonable expectations of either Picciotto or the editors of the special issue, and I withdrew it, with the positive consequence that an excellent paper by Picciotto alone appeared in that special issue.

The difficulty was that my paper which, as it left my hands, was dominated by an argument that, as an acute reviewer put it, 'Left-wing regulatory theory consistently undersells its own large ambitions by failing to establish a positive theory of the market'. This was not the right way to approach a general review of 25 years of the achievement of left-wing regulatory theory. It says something about the objectivity of my colleagues on the Editorial Board of this journal that they nevertheless insisted that, after I withdrew it, my draft paper should be reviewed as an, as it were, ordinary submission, and subsequently decided to publish it, though it certainly has the purpose the reviewer described.

I am grateful to Picciotto, those involved in editing the special issue, the Editorial Board, and their reviewers for the roles they have played in this paper appearing at all. 


\section{Introduction: Economy, market, regulation}

When writing the preface to a 1976 edition of The Road to Serfdom, Friedrich Hayek (1944/2007: 54-55) bemoaned the way that the prevalent definition of 'socialism', which when he first drafted the book in the early 1940s 'unambiguously' had meant 'nationalisation of the means of production and ... central economic planning', now meant 'the extensive redistribution of incomes through taxation and the institutions of the welfare state'. If it was Hayek's point that in debate one should not evasively shift the meaning of crucial terms, then, of course, his point had merit, for the principled conduct of debate does require something of the discipline of the duel from its participants. But he was also making a different point. He recognised that this shift in its meaning had made socialism more acceptable, though he did not at all concede that it made it ultimately acceptable, and the last book he wrote, The Fatal Conceit (Hayek 1988), was a restatement of his profound rejection of socialism in terms suitable to the late $80 \mathrm{~s}$.

Socialism as Hayek understood it in the 40s had by 1976 become theoretically indefensible, in large part because central economic planning had over that period itself become generally acknowledged to impose impossible burdens of information gathering and computation on planning agencies. This was, of course, to no little extent a result of Hayek's own contributions to the pre-war 'socialist calculation' debate (Hayek 1940/1997) and to the eventual political success of the 'neo-liberal revolution' in the 70s. On what is now seen as a significant event in the history of that revolution, in 1974 Hayek took the award of the Nobel Memorial Prize in Economic Sciences as the occasion for an Address on 'The Pretence of Knowledge' maintained by an economics profession which, beset by a 'feeling of ever growing power', had showed no 'humility' about the tasks it undertook (Hayek 1974/2014: 372), and so had 'made a mess of things' (ibid: 362). 
In this paper I will argue that what will be called 'left-wing regulatory theory' currently is undermined by a failure to more than gesturally take onboard this critique of the possibility of central planning, which I regard as irrefutable. The starting point of this argument is to note that, over the now 45 years that Social and Legal Studies and its predecessor The International Journal of the Sociology of Law (itself formerly The International Journal of Criminology and Penology) have appeared, 'regulation' has undergone as profound a shift in meaning as has socialism, made, indeed, in response to it being no longer plausible to outright deny that central planning is impossible. Regulation denoted, and of course in some important current uses still denotes, a particular degree of, to adopt Philip Selznick's (1985: 363) widely employed definition, 'sustained and focused control' over economic activity 'by a public agency'. Such control may take the form of public ownership of economic organisations or the subjection of privately owned economic organisations to a (far) more extensive regime of public rules than that to which such organisations would normally be subject. But, in part because of the neo-liberal revolution in economic policy and in part because of the left-wing responses to this, in its prevailing current use regulation has lost its connotation of being restricted to the specifically 'regulated' industries and has become coextensive with economic activity as such, regardless of whether economic organisations are in public or private ownership or are or are not the particular focus of a specific public agency.

The 'privatisation' or 'marketisation' of public provision (Osborne and Gaebler 1992) marks a most important shift in the nature of such provision (Daintith 1979), though it is essential to recognise that the state still, however tenuously, retains ultimate direction of and responsibility for the characteristic regulatory institutions of recent times, hybrid 'quasimarkets' (Le Grand and Bartlett (eds) 1993)). The impression of regulation becoming allencompassing is strengthened when the focus is turned away from the nation state no longer 
thought to be regulation's sine qua non to the transnational governance that is the basis of globalisation (Horsman and Marshall 1994). Prior to the late 70s, certainly in UK legal academic literature (Daintith 1989), the term regulation would not have been used to describe much of what it would now be thought to be gauche not to regard as regulation of some form. ${ }^{2}$ But the very distinctions that used to structure earlier debate - between private and public, between market and hierarchy, etc - have been eroded in the now dominant concept of a ubiquitous 'regulatory state' (Majone 1994), the first use of that term being, I believe, traceable to 1986 (Seidman and Gilmour 1986), which has created 'regulatory capitalism' (Levi-Faur 2017). This shift in the meaning of regulation can be instructively traced through the theoretical work of perhaps the central contributor to that shift, John Braithwaite, which reaches back to the late 70s (Braithwaite 1981-82; 2008). Regulation in the contemporary, 'thick' (LeviFaur 2013) sense is characterised by its great scope and the great range of the ‘tools' used to regulate (Hood 1983).

Whilst a wide definition of regulation will be put forward here, the purpose of that definition is not to attempt to give order to the now huge range of usages of regulation (Baldwin et al 2012: chs.7-8; Ogus 1994: chs.1-4; Prosser 2010: ch.1). The purpose of this definition is to focus attention on the real social processes that have driven, and are reflected in, the expansion of the meaning of regulation. It is obvious that this expansion follows from regulation being so important a concept that its definition is 'essentially contested' (Gallie 1956). It is nevertheless possible to identify the main issue of contestation.

Modern economics are based on a concept of the general economy of liberal democratic society as a spontaneous order. Exchanges between individual economic actors are overall unplanned but from them spontaneously emerges a stable order which is now all but universally called a market. The claim to legitimacy of the market rests, first, on its actually being a possible, or, more exactly, a stable order in the way that a centrally planned economy 
cannot be. It is important to acknowledge that this is to some extent a merely empirical conclusion (Fukuyama 1992). For whilst we know the economic (as well as other) reasons for the instability of a centrally planned economy (Nove 1982; Kornai 1992), we by no means have an adequate theoretical understanding of the stability of market order. This presumably is why we continue to use what is, to those employing it now if not to its author, who saw in it the working of Providence (Smith 1759/1976: 236), the mere metaphor of the 'invisible hand' (Smith 1776/1976: 456) as our principal way of describing market order. That, taken literally, Smith's explanation of market stability is now generally thought unacceptable has not meant that we have been able to replace it with an adequate alternative. ${ }^{3}$

In this situation, the continuing centrality of the market to modern economics rests, secondly, on the claim that market order is, not only stable, but also uniquely efficient. It is most important to grasp what is meant by 'efficiency' of this sort. The legitimacy of the (properly delineated) market as a sphere of liberal democratic society (Walzer 1983: ch.4) is based, not on the social goal of production of a particular set of goods, but on the extent of the freedom of that society's citizens qua economic actors to set their own, personal goals. The claim that the market economy is efficient is not a measure of the technically efficient production of socially valued goods but of the degree that the production of goods is determined by the voluntary choices of individual economic actors. In an economy conforming to the theoretical conditions of general competitive equilibrium, goods will be allocated entirely according to such choices in a state of 'Pareto optimal' welfare.

If voluntary choices spontaneously yield a stable order, then, not merely is overall coordination unnecessary, but it is essential that it be avoided. Because it alters the results of voluntary choices, intervention in order to achieve a publicly determined goal, a 'fair' allocation of goods or whatever, analytically cannot yield an allocation of goods which can claim to be efficient in the way that a market allocation can, for actual market efficiency is 
the voluntary allocation of goods. The efficiency of market order lies in a sort of symmetry: it is driven by voluntary exchange and works only if it is so driven. The general policy prescription which follows from this is, of course, laissez faire, which Smith saw as a necessary corollary of belief in the invisible hand:

it requires no more than to leave [Nature] alone and give her fair play in the pursuit of her own ends that she may establish her own designs ... Little else is required to carry a state to the highest degree of affluence ... brought about by the natural course of things (Stewart 1794/1980: 322).

The market economy's claim to legitimacy, in the first instance a claim to be the only possible form of ordering a modern economy, is, then, bolstered by the way that, looking at the issue as it were in reverse, order is an emergent property of voluntary choices, which is a claim to institutionalise individual economic actors' freedom through laissez faire.

The theoretical opposition between laissez faire and regulatory reform which came to identify nineteenth century 'philosophical radicalism' (Dicey 1914/2008; Halévy (19011904/1959) undoubtedly was not the result of 'design' (Atiyah 1979: 236) but rather was a generalisation from the accumulation of specific public responses to the many, various and profound ills caused by capitalist development (Taylor 1972) which eventually came to be analysed as social costs (Kapp 1950/1978). Nevertheless, we can now see that regulation analytically involves a challenge to the concept of the general economy as spontaneous market order, for it rests on a claim that welfare enhancing economic action of any sort is impossible without the involvement of public agencies. It is, however, misleading to speak of 'a challenge'. The theory and practice of regulation embrace a range of differing challenges to spontaneous market order, and those challenges are characterised, not merely by muddle that is obvious - but by a muddle expressive of indecision about whether regulation should seek to support or reject markets. Ultimately, this indecision is the indecision which has characterised left-wing economic policy since central planning became discredited. In the wake of this discrediting being accentuated by the successes of neo-liberalism, it has not been 
intellectually credible, despite the continuing popular success of statements of 'anticapitalism' (Mason 2016), to outright reject the market. Nonetheless, much left-wing theory and practice of regulation still is driven by the aspiration to do precisely this. But if the market should, indeed must, be the general economy of the liberal democratic societies, this aspiration is no more than an incoherent romanticism which undermines the development of the concept of the social market that I will claim is immanent in regulation.

\section{A taxonomy of regulation derived from Pigou}

I have mentioned that I will adopt a wide definition of regulation, and, taken from Ronald Coase (1977: 5), it is: 'Economic regulation is the establishment of the legal framework within which [legitimate] economic activity is carried out'. Coase goes on to say that he intends this concept to include, not only action by executive agencies (ie government), but also the actions of the legislature and the courts. This expansion of the institutions which are to be considered as part of regulation is wise, but it is not this that I believe is the most valuable feature of Coase's definition. Selznick's definition considered above deliberately eschewed width in order to focus on control by public agencies. Such control is not, however, an essential part of Coase's definition. This is of value because I believe it is very important indeed to distinguish regulation which seeks to control from regulation the virtue of which is precisely that it does not seek to control. Something like this distinction is driven at in the common separation of the categories of 'social' and 'economic', or 'interventionist' and 'non-interventionist' regulation, all of which Coase's definition of regulation can embrace.

\section{Social regulation or intervention}

Social regulation seeks to control economic activity in the sense that it seeks to impose a 'pattern' (Nozick 1974: 155-60) on such activity by state intervention. Though what can 
accurately be regarded as social regulation has, of course, a long (much longer than is often acknowledged) and complex history (Ogus 1992), the intended alteration of some of the outcomes of a market believed to be 'generally beneficent' was put on its modern, welfare economic footing by AC Pigou (1920/2002: 128). Concern about the ills of capitalist development had been given a central place in economics by Sidgwick and Marshall, Pigou's predecessors in the 'Cambridge School' of economic theory, and Pigou's great significance lies in the degree of his success in placing Victorian responses to those ills on a unified theoretical basis. Pigou's reputation was terribly eclipsed by that of Keynes during the latter part of their lifetimes, and Pigou's influence has only relatively recently been adequately recognised (Aslanbeigui and Oakes 2015; Kumekawa 2017), in substantial part because of the attention which Coase's criticism of intervention (1960/1986: 133-42), which very insightfully focused on Pigou, has drawn to him.

Though the terminology he employed when doing so, of the divergence between private and social net products of an investment, has fallen into desuetude, it was Pigou (1920/2002: pt.2, chs.2-4) who formulated the concept of what are now called negative and positive externalities. Externalities are market failures generating social costs in the strong sense that, even though the market is allocating goods according to the voluntary choices of private economic actors, those choices are themselves believed to be in important respects mistaken and that allocation therefore diverges from the social optimum. Pigou considered a wide range of remedial interventions but focused on taxing activities causing negative externalities and giving bounties to encourage activities which would counter positive externalities. His example of harm inflicted by factory smoke which takes place because the factory operator does not have to compensate those harmed as it has no market relationship with them regarding the harm (Pigou 1920/2002: 184) has become the paradigm of a negative externality calling for intervention. Pigou's political views were sympathetic to socialism but, 
whilst he seems to have acknowledged the possibility of an ultimately completely socialist economy (Pigou 1937: 137), his views were so gradualist that he was for all intents and purposes committed to a mixed economy. His views were not intended to be a precursor to central planning and in this way he is the source of the economic case for 'piecemeal' intervention (Popper 1966: 158). But though Pigou certainly theoretically conceived of intervention as a set of exceptional measures taken in a general market economy, piecemeal intervention has now become extremely extensive indeed, and I shall return to this.

Reasons of space preclude discussion of the development of Pigou's basic thinking in subsequent welfare economic theory, principally the theory of Kaldor-Hicks compensation (Kaldor 1939: 550; Hicks 1941/1981: 105) and the practice of cost benefit analysis (Foster and Beesley 1963/1973). I wish to stress one point. Regardless of the particular economic theory which informs it, in social regulation the outcomes of voluntary choices in the market are judged from an hierarchically superior viewpoint, and, if the assessment is to some degree negative, intervention intentionally designed to alter those outcomes may be implemented. The social perspective from which a Pigouvian judgement that private and social costs diverge has to be the perspective of the state. Intervention is a coercive transfer which can be carried out only by the state because it ultimately rests on the monopoly of violence. Loose talk of regulation by 'society' in the 'public interest' is a misleading instance of what Whitehead (1926: 72) called 'the fallacy of misplaced concreteness' which detracts from consideration of the crucial issues. In his 1937 book The Good Society, which Hayek regarded as a model for The Road to Serfdom, the now largely forgotten but at the time extremely influential American journalist and commentator Walter Lippmann (1937/2005: 175) acutely observed that 'when the collectivist abolishes the market place, all he really does is ... locate it in the brains of his planning board'. 
That it ultimately rests on coercion does not, of course, mean, save to anarchists (whose views will be, unfairly given their interest, ignored), that we should eschew social regulation, and the difficulties in determining (Feintuck 2004: chs.1-2) and realising (Hawkins 2002: chs.1-2) the public interest do not make intervention always unjustifiable. That there are occasions for intervention was something which Smith (1776/1976: 687-88) himself certainly did not deny in relation to the government agencies of his time, and the practical welfare economics of the developed welfare state have to contemplate a great number of second, not first, best choices (Lancaster and Lipsey 1956) which must be given effect by coercive transfers. Every sensible commentator, no matter how committed to market organisation, allows the possibility of intervention. In the UK, Anthony Ogus (2006) encapsulates the wisely catholic attitude I am trying to describe. But that social regulation $i s$ coercive and that determining and effectively acting in the public interest are difficult do mean that, first, there is a prima facie case against intervention; and, secondly, that intervention can never partake of market efficiency, for, as we have seen, market efficiency has to be voluntary.

\section{Economic regulation}

The most important issue in social theory and economic policy is whether, in order to exist, a market must be subject to economic regulation. On the basis of Coase's wide definition of regulation, it would seem that this must be the case. But our understanding cannot be driven by mere definition. We must decide whether the market is a fundamentally spontaneous form of organisation requiring no regulation, a free market as it is generally put, or whether the market requires economic regulation in order to exist. In order to make this decision, two senses of regulation bound up in the concept of economic regulation must be distinguished. These may be called ex ante and ex post regulation. The first addresses the establishment of a framework for economic activity and the second its maintenance. 
Ex post regulation. Let us first consider ex post regulation, having assumed that a market economy has been established. The question arises whether that economy is capable of what Marx called reproduction (Marx 1867/1996: 565-66), and Marx, of course, himself believed that the capitalist economy was incapable of this (Marx 1885/1997: 520-22). Since the late nineteenth century, corporate capitalist economic policy has been based on an acceptance of variations of the two fundamental reasons Marx gave for this belief: over-production (or under-consumption) (Marx 1894/1998: 245-58) and the centralisation of capital (Marx 1867/1996: 619-23). Keynesian demand management has been thought necessary to counteract a structural tendency of the capitalist economies to be unable to sustain full employment (Keynes 1936: ch.3). Competition policy of some sort has been thought necessary to counteract a structural tendency towards monopoly. We have seen that Pigou believed social regulation might be necessary even if competitive market conditions obtained, but he also believed that economic regulation of monopoly was necessary to ensure that those conditions obtained as widely as possible (Pigou 1920/2002: 336).

Pigou also saw potential value in certain measures which would improve economic actors' ability to conclude optimal exchanges, including increasing the information available to those actors, though he did not give these any sustained consideration (Pigou 1920/2002: 145-46). WH Hutt, who coined the term in the 30 s, argued that 'consumer sovereignty' could find 'its full and untrammelled realisation' only within 'a framework of competitive institutions' (Hutt 1936/1990: 261). With some hesitation, I would suggest that special measures of what is now called consumer protection should be regarded as ex post economic regulation, for, when they are not outright interventionist, such measures seek to improve the operation of markets by addressing instances of 'imperfect competition' within a market economy regarded as basically competitive. Without at all going into the theory, this, as it 
were, restricted approach is by no means consistent with all versions of the economics of imperfect competition, but even this approach regards these instances as common, and so consumer protection is clearly wider than, and distinguishable from, the specific issue of the regulation of monopoly, as one of the leading contributors to the analysis of monopoly strongly maintained (Chamberlin 1962: 6-7).

To the extent that it correctly identifies structural tendencies of the market to undermine itself which it seeks to counter, it might be said that ex post economic regulation seeks in a sense to impose non-market outcomes. Nevertheless, such regulation should be classified as economic rather than social because it is not intended to pattern the outcomes of the market rendered capable of reproduction. The distinction I am trying to make underpins Keynes' at first blush strange claim that his views were 'moderately conservative' because he sought to alter the volume but not, save as was necessary to alter volume, the direction of private investment, as he saw 'no reason to assume that the existing system seriously misemploys the factors of production which are in use' (Keynes 1936: 379). This was a profound criticism of Pigou because the correction of such misemployment is, of course, the entire point of Pigouvian social regulation.

Ex ante regulation. Having noted the unarguably oxymoronic aspect of the concept of ex post economic regulation, let us turn to the concept of ex ante economic regulation. The question must be asked whether a general market economy can exist at all without legal regulation establishing it? We can again put anarchism to one side, for though we must later briefly consider deregulatory responses to this question, the overwhelming majority of such responses are not literally anarchist, though they often do confusingly seek to utilise the rhetoric of anarchism. Pigou himself acknowledged that the pursuit of self-interest which motivates economic action can readily take unwelcome forms, such as mere appropriation by 
violence or deceit, and accepted without much argument the necessity of a legal framework which channelled self-interest into the beneficent channel of exchange as an essential condition of market order (Pigou 1920/2002: 127-30). It is highly significant that Coase, whose attack on intervention focused, as I have mentioned, on Pigou, had no difficulty in accepting this (1960/1986: 134), though that attack overall is of comparable significance to Friedman's attack on Keynesian macroeconomics in the history of neo-liberalism. But in this part of his argument for regulation Pigou was merely accepting a position which had been all but universally accepted in economic (Smith 1776/1976: 687), legal (Austin 1998: 201-204) and political (Kant 1764/2007: 113) philosophy, that a solution to what Parsons (1968: 89-94) identified as the Hobbesian problem of 'normative order' is integral to the possible existence of the market economy. But though a stable market must be a normative order ultimately based on public regulation, the crucial point is that the public regulation should facilitate private action. ${ }^{4}$ In The Good Society, Lippmann (1937/2005: 267) put the point this way: 'in a free society the state does not administer the affairs of men. It administers justice among men who conduct their own affairs'.

The fundamental difference between social and economic regulation is that the former pursues a specific politically defined public goal, but the latter should seek to maintain neutrality (Nozick 1974: 33) between the ends of individual economic actors. One can say that it is the social goal of the market economy to avoid the identification of social goals. As it is at the heart of the entire conception of liberal democracy, neutrality, obviously itself essentially contested, has been conceived in a great number of ways. Barry's (1965/1990: 3841) distinction between 'ideal-regarding' and 'want regarding' principles perhaps best captures the sense of neutrality at which I am trying to drive here. Of course, that liberal democratic society is based on a market economy regulated by want-regarding principles does not mean that private and public debate over the moral value of economic choices 
should not take place. But it does means that an actor's choices, once decided upon, should not be politically second-guessed. De gustibus non est disputandum is a foolish maxim for the guidance of one's personal conduct. Reflection, especially in light of the views of others, on the wisdom of one's courses of action, including choices of economic goods, is so much a personal moral duty that it is part of the autonomy of human action as such. But de gustibus non est disputandum should be the basis of economic policy in the market economy.

The crucial point about neutrality that should immediately strike those concerned with the formulation and implementation of practical regulation, though it has sometimes emerged from abstract political philosophy (Weale 1985: 27), is that neutrality cannot adequately be conceived as a passive principle but must be conceived actively (Hale 1923: 471). The state must desist from second-guessing, but this is not nearly enough. It must ensure that the choices which are made have effect, ie that the market works, and this is a matter of extensive and complex effort. Even when it strives to maintain neutrality, ex ante economic regulation of the developed market economy involves ensuring both that the institutions which must be established are sufficiently elaborate and that, as the processes involved are reflexive, those institutions are continually renewed, for as economic actors respond to regulation, the regulation must in turn respond to the moves of the actors; a process Luhmann (1995: 471) called 'hypercomplexity'. But the rhetorical tendency of laissez faire is towards passivity, and economic policy has been tediously handicapped by the invariably minimalist view of the role of the state (Campbell 2003b: 56-57; Campbell and Klaes 2005: 278-89) - the mere prevention of force or fraud as JS Mill (1848/1965: 936) said of laissez faire - which follows from understanding economic regulation in a wholly negative way, as a mere cost rather than as the essential public facilitation of private economic exchange (Campbell and Picciotto 1998: 251-53). 
Despite its great influence, there is little need, given this article's anticipated readership, to criticise the neo-liberal fantasy of literal 'deregulation' which, in legal theory, has been predominantly expounded by Richard Posner, unarguably the world's most influential legal theorist and jurist of the neo-liberal period. I have put forward such criticism elsewhere (Campbell and Picciotto 1998; Campbell 2012) and, in light of the financial crash which was principally caused by policies which described as deregulation the all but total capture of financial regulation by finance capitalists, even Posner has abandoned deregulation, albeit in a depressingly uncomprehending manner (Campbell 2010a). It is far more important to note that 'reregulation' as a criticism of 'deregulation' has been at the heart of responses to the neo-liberal revolution (Majone (ed) 1992), and it would be redundant here to set out the theoretical argument for the necessity of extensive regulation of the process of 'marketisation' if that process is to increase welfare (Vogel 1996). In sum, productive deregulation has to be regulated (Aalbers 2016). This argument has actually been much strengthened by the deplorable experience of neo-liberalism when deregulation has actually been given something like literal effect. This experience has, however, been far more the experience of what formerly were called second and third world countries, subjected to such actual horror by what once was hailed as the Washington consensus that even the foolish international organisations which imposed that consensus have themselves abandoned it (Campbell 1999; Tshuma 1999), than it has been the experience of the formerly first world countries themselves, for there deregulation is a myth.

The point that is worth making here is that in its typical left-wing statement the insistence on the necessity of ex ante economic regulation tends to eliminate the recognition that what is being regulated is market action the nature of which is in some way ontologically prior to the regulation, and so has its own determining principle separate from, though obviously profoundly affected by, that regulation. The defining foolishness of the idea of 
literal deregulation is that the specific form of corporate capitalist markets are ineluctably given, indeed natural, and, writing against this background which Posner gave such currency in legal theory, Sunstein has, in an influential statement, told us that:

The notion of "laissez faire" is a grotesque misdescription of what free markets actually require and entail. Free markets depend for their existence on law ... The point is not by any means a critique of free markets. But it suggests that markets should be understood as a legal construct, to be evaluated on the basis of whether they promote human interests, rather than as a part of nature and the natural order, or as a simple way of promoting voluntary interactions (Sunstein 1997: 5).

But even if one accepts the critique of taking markets to be 'part of nature', what are we to understand to be necessary to 'promote human interests' if those interests are strongly distinguished from 'the natural order'? Smith traced the achievements of 'commercial society' (Smith 1762-66/1978: 14) to the way its institutions gave rein, in a way that previous 'rude' societies did not, to a human 'desire of bettering our condition' (Smith 1776/1976: 341), and this desire, and 'all the toil and bustle of this world' to which it gives rise, though betterment is by no means restricted to merely material acquisition (Smith 1759/1976: 50), makes no sense outside of the context of scarcity of economic goods. The achievements of commercial society, especially the establishment of the general division of labour, were possible only because of the liberation of 'a certain propensity in human nature ... to ... exchange one thing for another' (Smith 1776/1976: 25) driven by the desire of betterment. Without, in truth, really recognising the profundity of the issue, ${ }^{5}$ Sunstein is broaching the fundamental question posed by all truly radical critique of market order: is market order but one social form of order which, because it is merely social, we are at liberty to alter as we wish if we are able to marshal sufficient political will to do so, or does market order in some way actually reflect an existential, and in this sense natural, property of economic life as human intercourse with nature? I am gratified that my own writings have been cited as authority for rejecting the conflation of actually existing capitalist institutions with natural givens (most recently Attenborough 2017: 213). But this is not to say that the market 
economy cannot be justified because of the way it relates to natural givens, and I believe that it can be so justified, though actualising that justification requires the creation of market socialism. Even the best regulatory literature simply does not contain the resources to confront this issue head on, and I shall turn to the work of the figure whose argument that market order should be completely abandoned is by far the most profound such argument ever made: Karl Marx.

\section{The roots of the problem in Engels and Marx}

The theory and practice of regulation are, as with so many issues in social theory generally, now discussed with but little reference to Marx, who is no longer so much feared and reviled as regarded as an irrelevance or even a figure of fun. The significance of the scarcely credible but, as Althusser would have said, symptomatic success of Thomas Piketty's (2014) Capital in the Twenty-first Century is that though, as with its title, it used Marx's profound analysis of capitalist contradictions and tendencies merely as rhetoric, this was enough to invest an almost meretricious book with an air of profundity. Piketty is in fact largely ignorant and disdainful of Marx's work and his book has no meaning sufficiently concrete to ground any policy other than a general expansion of expenditure by the state (Campbell 2015). However, in its background longing for a non-market general economy, Piketty's book exemplifies the left-wing way of looking at the issues, the foundations of which can best be rendered explicit by examining Engels' and Marx's views on socialism.

The foundation of these views is that they claim to be 'scientific'. Engels and Marx were profoundly sceptical of what they regarded as purely moralistic or utopian criticism of capitalism, with Marx (1867/1996: 17) famously refusing to write Comtist recipes for 'the cookshops of the future' and Engels (1880/1989) basing perhaps the most successful political writings of modern times on emphasising a theme, undoubtedly present in Marx's 
(1871/1986: 335) own thought, that communism would be the result of objective processes, in some important way akin to those studied by the physical sciences, at work in capitalism. To this end, Marx did indeed analyse capitalism in a way which very creditably observed the protocols of social science, and in particular Capital was based on the most thorough critique of classical political economy which had at that time been attempted. But, for reasons which cannot be explored here but which turn on the relationship of the, in itself very valuable, 'active' philosophical anthropology of labour Engels and he had developed in their early work to Marx's later economics (Marx 1867/1996; 187), Marx believed that communism would eliminate scarcity and thus allow of the elimination of work as a burdensome activity (Marx and Engels 1845/1976: 47; Marx 1894/1998: 807). This belief is very profoundly mistaken (Schmidt 1962/1971: 163), and maintaining it erased any appreciation of the distinction which must be drawn between 'existential dichotomies' and 'historical contradictions' (Fromm 1947/2003: 31), though such a distinction had been central to the conceptual analysis of the 'general' and 'specific' elements of modes of production Marx wrote whilst preparing what was to become Capital (Marx 1857-58/1986-87: vol.28, 17-48).

The end of scarcity cannot properly be derived from Marx's critique of classical political economy. As has been mentioned, scarcity is central to the views of Smith, despite his intense focus on the social organisation of labour as the most important cause of economic improvement and his belief that commercial society could normally provide for generous subsistence without difficulty (Smith 1776/1976: 10). For Smith also saw that the 'endless' expansion of demand for ever more refined goods was the essence of civilisation, and 'a demand for every sort of material which human invention can employ' (ibid: 181) analytically must encounter scarcity. But though Engels and Marx (1848/1976: 489) themselves celebrated this expansion of demands as a central part of their insistence that capitalism had 'historically ... played a most revolutionary part' (ibid: 468), they also 
attempted to place a limit to that expansion by distinguishing demands satisfied by 'necessary' as opposed to 'free' labour (Marx 1867/1996: 807), with the 'prime want' satisfied by free labour being for labour in itself (Marx 1875/1989: 87). This is not, in my opinion (Campbell 2003), even coherent, and I shall return to this.

The 'marginal revolution' which, for good and ill, shifted the focus of economics away from progress in the production of wealth to the allocation of a given set of goods (Robbins 1935: 15) has the ultimate justification that economic action as instrumentally rational action does indeed turn on it being a response to scarcity of the means to satisfy demands (Weber 1922/1978: 24, 63), for we must recognise that scarcity in this sense captures one of 'the necessities to which human action is subject' (Robbins 1935: 135). As its core is the denial of this, Marx's concept of communism is irrelevant to the discussion of the problems which actually constitute economics (Nove 1983: 10) and politics (MacIntyre 1985: 260-62). Serious, or, perhaps better, determined, attempts, exemplified by the active Bolshevik campaign for the abolition of money during the period of 'War Communism' (Malle 1985: ch.4), to impose by force a communism at fundamental variance with the character of humanity's relationship with nature, inevitably have had consequences which it is supererogatory to describe here (Walicki 1995).

Marx wrote very little about the transition from capitalism to communism, but his predominant view involved an intermediary first stage of socialism (Marx 1850: 127). The point about socialism conceived in this way is that there is nothing intrinsically positive about it. It is 'in every respect, economically, morally and intellectually, still stamped with the birthmarks of the old society from whose womb it emerges', and 'these defects are inevitable in the first phase of communist society as it is when it has just emerged after prolonged birth pangs from capitalist society' (Marx 1875/1989: 85, 87). Later communist philosophy culminating in Althusser (1962/1977: 114-16) logically drew the conclusion that socialism, 
particularly the capitalist 'survivals' which characterise it, was itself something to be eliminated by fully developed communism.

On this basis, it is simply impossible to develop a coherent theory of socialism as a desirable form of economic organisation, indeed of ethical life, and inevitably the theory of market socialism on which left-wing economics and politics ultimately must depend after the acknowledgement of the impossibility of central planning has remained vestigial and ad hoc. In recent times, the best that has been able to be done is yet again to celebrate the rhetorical trope of the 'third way' (Giddens 1998) as if it was more than merely a trope which confesses the absence of a concrete general position: social democracy's equally tedious parallel to dialectical materialism's reduction of the dialectic to what Hegel had called a 'monotonous formalism' (1807/1977: 30). The risible self-congratulation about their daring novelty displayed by many of the leading contemporary exponents of the third way (Mandelson and Liddle 1996; Mandelson 2002) is merely the result of ignorance (Diamond (ed) 2014) of the fact that left-wing economic policy, ever since it has had to distinguish itself from Bolshevism, if not indeed since revisionism distinguished itself from theoretical communism (Bernstein 1899/1993), has had the third way at its heart. In the early 30s one finds Beveridge (1935/1936: 107) looking for a 'halfway house between Cobden and Lenin' and Keynes (1934/2013: 32) for a 'third alternative' to Asquith and Stalin.

The theory and practice of left-wing regulation examined here is based on such ad hocery. In the absence of a general theory of market socialism, regulation is an accumulation of responses to cries du coeur about the operation of the market which, for merely empirical reasons, achieve political resonance. The parallel with the lack of design behind nineteenth century responses to laissez faire, and the evident failure to learn from the past, is truly depressing, but it is not the worst feature of such regulation. In their completely negative attitude to the market, such cries are a communism that dare not speak its name, one reduced 
to a mere romantic longing for the lost aspiration to put Mammon behind us and run the economy in the public interest which seemed to have been on the brink of being realised in the post-war 'Golden Age' of capitalism, only then to be thwarted by neo-liberalism (Marquand 2015). The very influential Golden Age views of Tony Crosland, perhaps the intellectual leader of the last generation of leading Labour politicians who had any real grasp of the fundamental social theoretical issues (Reisman 1997a; 1997b), turned on his belief that, 'the political authority has emerged as the final arbiter of economic life [and the] era of unfettered market relations is over'. So competent was this authority's economic management that 'questions of economic efficiency' were no longer 'of primary importance' in a Britain which stood "on the threshold of mass abundance'. Were he then to have been asked whether the UK continued to be 'capitalist', Crosland would have answered 'no' (Crosland 1956: 73, $515,76)$. In what passes for current political debate, views like Crosland's have been reduced to a reluctance to squarely address issues of resource constraint which gives an air of frivolousness to much left-wing policy.

I myself believe that reproduction of the regulatory successes of Golden Age social democracy is a worthwhile general goal, but perhaps reproduction is the wrong word. Attempted reproduction would constitute a mere nostalgia which fails to ask why those successes were undermined by ignoring resource constraints in a way which did, and does, lead to the shortcomings of the public realm that provided an important basic justification for neo-liberalism. It will be recalled that in the quotation given earlier, Sunstein, having said that the point that 'Free markets depend for their existence on law ... suggests that markets should be understood as a legal construct ... rather than as a part of nature and the natural order', also said that 'The point is not by any means a critique of free markets'. As Sunstein says nothing positive about such markets but focuses only on market outcomes that should be 'regulated' so that those outcomes satisfy his improving standards, this is simply a failure of 
nerve. It is an instance of what Hegel (1807/1977: 221-35) described as the clash of 'virtue' with 'the way of the world', in which the ethical superiority the former claims over the latter is exposed as self-deception emerging from the failure of virtue to have a secure understanding in the world it seeks to improve. It has left us with a left-wing approach to the market that, absurdly, is all market failure.

One cannot really be sufficiently critical of Engels' and Marx's failure to say much or really anything concrete about labour under communism. But in one respect their views about the abolition of scarcity do in part excuse what seems to be an even greater lacuna: the absence of a plausible theory of the state under socialism and communism. For if communism abolishes scarcity, surely the vast majority of occasions for conflict are removed and the state will 'wither away' (Engels 1878/1987: 268). Whatever one may think of this, it does at least envisage a limit to the power of the state. Despite their untempered rejection of anarchism, exemplified by their unjustified dismissal of those of Bakunin's (1873/1990: 17879) views which proved to foretell the future of actually existing communism, the fundamental attractiveness of Marx and Engels' politics lies in the anarchism of their belief that the communist state would eventually wither away. What comparable limit can emerge from regulation which has given up explicitly advocating general planning but nevertheless is communist in sentiment and so puts forward endless criticisms of, and therefore proposals for intervention in, a market for which it has no positive role? Such criticism of the market can know no bounds save the ingenuity of those identifying market failure, their confidence in their capacity to improve things by intervention (ie their ignorance or disregard of the resource constraints and other difficulties), and their capacity to influence the political situation.

Though it is extremely unfair to focus on just this aspect of these works, it must be said that a prominent strand of much leading left-wing writing on regulation, including writing 
which has appeared in Social and Legal Studies and its predecessor, is a concern to improve the, as it were, technical effectiveness of regulation. This is, of course, in itself welcome, and indeed exploration of the limits of the formal law in ensuring the effectiveness of "social control' as part of the general criticism of command and control is a major intellectual source of modern regulatory theory (Bardach and Kagan 1982), and it has produced a very impressive corpus of work on the complexity of compliance and of 'responses' to this (Ayres and Braithwaite 1992). But effectiveness cannot be a goal in and of itself because not all means of securing effectiveness are consistent with acceptable state practices, and certain practices must be eschewed, even if this means reduced effectiveness. Recognition of this played an important part in the very conception of democratic socialism (Tawney 1935/1981: 165-66). But it must be acknowledged that there is now an unattractively statist strain of leftwing views about the possibilities of regulation (Campbell 2002; 2010b: 507-34) that do not give this consideration appropriate, or even any, weight, in which the elaboration of sophistic and sophisticated techniques of government 'draws gasps of admiration for the efficiency of what is in effect lawlessness' (Goodrich 2009: 310).

Regulatory theory of this nature is unarguably open to the neo-liberal criticism that it is not consistent with the rule of law (Hayek 1982, vol.2). And surely a great opportunity for left-wing regulatory theory is being missed. Orwell (1944/2001) reviewed The Road to Serfdom and found its liberal aspiration attractive, but unconvincing. Returning to it two years later, he stated the reason it was unconvincing in the particularly direct way typical of him:

Hayek's able defence of capitalism ... is wasted labour, since hardly anyone wishes for the return of old-style capitalism. Faced with a choice between serfdom and economic insecurity the masses everywhere would probably choose outright serfdom, at least if it were called by some other name (Orwell 1946/2001: 59). 
Expansion of the scope and scale of regulation does expand the possibility of curtailment of liberty, but, leaving aside other points that must be made, it is the purest wishful thinking to believe that the response to this should, or even could, be to 'shrink' that scale and scope in a way that would abandon the core achievement of the welfare state (Feigenbaum et al 1999). Our task is to so develop the theory and practice of regulation as to show that it is reconcilable with the rule of law (Plant 2010; Scott 2010) and so 'make constitutional sense of the liberal activist state' (Ackerman 1985: 357). Left-wing regulatory theory, which naturally should recognise the ineluctable diversity of legitimate perspectives on policymaking, should have the enfranchisement of repressed perspectives through democratic participation at its core (Picciotto 2011: 463-68). But very arguably it has not. Placing far too much emphasis on 'output' rather than 'input' (or 'process') legitimacy (Scharpf 1999), leftwing regulatory theory has come to connote technocracy: 'Specialised agencies, staffed with neutral experts, can carry out policies with a level of efficiency and effectiveness that politicians cannot' (Majone 1996: 4).

All this is exemplified - I acknowledge it is an extreme example but its very extremism makes its great success again symptomatic - by 'nudge' theory, which uses influences of which the subjects of regulation are intendedly not (fully) conscious in order to secure compliance and therefore effectiveness. Nudging certainly embraces, and I would say is typified by, deceit (Campbell 2017). Sunstein is the leading legal academic proponent of nudging (Thaler and Sunstein 2009), and it is troubling that his criticism of markets, which at least have respect for economic actors' choices as their principle even though that principle can be (very) defectively given effect, seems to have led him to progress from maintaining the strong possibility of regulatory second-guessing of such choices (Sunstein 1990: 40) to a technique of social regulation which has disrespect of choice as its principle. What one thinks of the aspect of regulatory theory exemplified by nudging will turn on how plausible one 
finds Sunstein's (2016) insistence that his justification of it as 'libertarian paternalism' (Thaler and Sunstein 2003) is more than the unscrupulous oxymoron it, in my opinion, certainly is.

In this promotion of a state so confident in its virtue that it can take this authoritarian attitude towards its citizens, not least towards their economic choices (Feintuck 2010), we would seem to have come a very long way from the radical left-wing emphasis on the (welfare) state's role in the reproduction of the corporate capitalist economy (Müller and Neusüss 1970/1978). This conception of ‘capitalist regulation' (Aglietta 1976/1979) stressed the intimate connection, indeed intertwining, of capital and state (Offe 1984: ch.8) in ‘corporate democracy' (Jessop 1978). These analyses of the function of the state certainly have weight, but for this very reason they acutely pose the question how such a state could possibly have a general capacity for regulation in the public interest? Arguments that this lies in the 'relative autonomy' of the capitalist state (Miliband 1983/2015) are persuasive of nothing save that such radical criticism has, in fact, no theory of the state which can underpin both its explanation of the state as 'inevitably the guardian and protector of the economic interests which are dominant in them' (Miliband 1969/1973: 237-38), and its, prima facie contradictory, wish to use the state to promote the public interest. Neo-liberal public choice theories of 'regulatory capture' (Stigler 1975), though they maintain a blanket opposition to the state which is ultimately irrelevant as it cannot even be consistently maintained, are, one has to acknowledge, no more theoretically incoherent.

The predominant result of ad hoc criticism of the market which knows no limits and a theory of the state which knows no limits to the state has been an extremely extensive growth of piecemeal intervention, to the point where it can no longer really be understood, or defended, as piecemeal because it is ubiquitous in, precisely, the regulatory state. The gestural equivocations about the market entered at a number of occasions in Piketty's Capital 
in the Twenty First Century are but brief counterpoints intended actually to add plausibility to its overall advocacy of further immense growth of the state (Campbell 2015: 205-206). But this growth is already unacceptably often counter-productive as the state undertakes so much that the marginal return to its activity can be negative (Coase 1974/1994: 62-63). This has to be understood in two ways. The state may intrude into areas where it should not. But, on the other hand, by spreading its capacity too thinly, the state may perform so poorly as to call into question the legitimacy of (ultimately) public provision even in areas where it should be appropriate. The common enough management failures of quasi-market or outright privatised formerly public provision merely exaggerate the underlying grave problem (Vincent-Jones 2006). This has led to important commentators entirely prepared (albeit to different degrees) to be sympathetic to intervention to conclude that the 'hyper-active' (Minogue 1978) or 'hyper-innovative' state has made 'fiasco' characteristic of government (Moran 2003: 17179). The only remedy for this is to ask again the fundamental question posed by the neoliberal revolution: what is the proper ambition of regulation?

\section{Conclusion: Regulation and the contemporary meaning of socialism}

The abandonment of central planning at the core of the neo-liberal revolution has found a very paradoxical expression in the theory and practice of regulation which has emerged from the left-wing responses to that revolution. Rhetorical acknowledgement of the indispensability of general market order is now all but universal, and similar acknowledgement of the generally superior 'efficiency' of that order is common. But the leftwing theory and practice of regulation tend not to be informed by an actual commitment to the market. Rather, indeed, they are normally informed by quite the other thing: a communism that dare not speak its name. This absence of a positive theory of economic action and market organisation represents a debilitating failure to recapture the 'rehabilitation 
of desire' in eighteenth century moral philosophy (Lasch 1991: 52) principally associated with Smith (1776/1976: 13-30), which established exchange as an enormously valuable form of the exercise of self-interest, the foundation, indeed, of the historically unprecedented progress achieved by commercial society. We have noted that Engels and Marx themselves celebrated the achievements of capitalism, and, like Smith, they saw this as no merely material achievement. For them, capitalism constituted 'an epoch in the development of the human race' (Marx 1867/1996: 85), the 'epoch of history that directly precedes the conscious reconstruction of human society' (Marx 1894/1998: 92), and so the epoch with which 'the pre-history of human society ... closes' (Marx 1859/: 264). It is, of course, extremely difficult simultaneously to utterly damn and fulsomely (this word is not nearly strong enough) praise capitalism: 'On the one hand, Marx is telling you in Das Kapital that a certain "historic" development, indispensable for the progress of the race, could only have been carried out by capitalism; and, on the other hand, he is filling you with fury against the wickedness of the people who have performed it' (Wilson 1940: 295). There is no need for modern left-wing thinking on regulation to reproduce this extreme difficulty, and a positive theory of market organisation which expunged its abiding communist yearning would be the basis of its solution.

Here again a great opportunity is being missed. In the anxiety to pursue ex post economic regulation which patterns, far too little is made of the potential of ex ante economic regulation to increase welfare which lies in grasping the socialist truth of markets, that they must have a detailed and extensive public foundation. Once specific market institutions are established, intervening to alter the outcomes they yield must run into the problems that led to the rejection of command and control, including failures to observe the rule of law, as legitimate expectations formed within those institutions must, ex hypothesi, be frustrated, and this will encounter resistance. I hardly claim that these problems disappear, but they are in 
principle changed, and greatly mitigated, if the issue is normally approached as one of ex ante economic regulation. The issue then is not one of overcoming resistance but of design of the institutions which precede the specific form of economic action, and so shape expectations and action ab initio. The direction of action in this way can, ceteris paribus, be much more readily justified than intervention and this is not least the case because, even when the intention is to maintain neutrality so far as possible, such direction is unavoidable. This point has been made in the most profound political philosophy ( $\operatorname{Raz} 1986: 117-24)$. Let me try to make it in terms of regulatory theory.

The 'invariance' argument derived from Coase's (1960: 2-8) 'The Problem of Social Cost' was an intellectual pillar of the worst aspects of the neo-liberal revolution. In Coase's famous rancher and farmer example, the allocation of a right to allow or prevent cattle straying onto crops did not, after negotiation, itself affect the number of cattle or the amount of crops grown, which negotiation would establish at optimal levels. Negotiation will indeed necessarily have this result, but only when transaction costs are assumed to be zero, for then all the negotiations required to reach the optimal outcome will inevitably take place as such negotiations are costless. This appeared to be a justification of deregulation, for if outcomes are invariant of the allocation of rights, regulation cannot play much or any positive role, so its only role appears to be negative. But this was exactly the opposite of what Coase overall wanted to demonstrate (Campbell 2016). For when transactions costs are positive, as Coase insisted was always empirically the case, the initial allocation of rights will have a profound influence on the outcome of negotiations, not least by preventing any negotiations ever taking place in many cases, and in every case such negotiations as do take place can never produce the theoretically optimum outcome. With the rancher and farmer, whether the former is or is not liable for the destruction of the crops does not, at zero transaction costs, ultimately affect the number of cattle (and so the crop yield) but only identifies which party has to start the 
negotiations about this. But with positive transaction costs, initial legal liability will certainly affect the number of cattle or the amount of crops. And, the point of relevance here, it is never possible to be completely neutral, even if one seeks to facilitate choice and avoid patterning. Either the rancher or the farmer must enjoy an initially superior position and this must effect the outcome of the bargaining which has been facilitated. Legal allocation of rights must indicate a preferred outcome, and so legitimately can indicate the outcome preferred.

What seems a major obstacle to taking this approach is that it requires detailed analysis of empirical institutions and empirical possibility. This requires much harder work than the speculative postulating of a desired pattern distanced or even divorced from such understanding, which surely is the basis of much government failure (Campbell 2017). And again Piketty is symptomatic (Campbell 2015: 209-213). He rightly sees the wealth of superstar celebrities and supermanager corporate executives as extremely objectionable features of corporate capitalism, and calls for extensive state action against these products of the market (Piketty 263-65). But superstardom rests on intellectual property rights (Campbell and Picciotto 2006) and supermanagers ultimately owe their positions to general limited liability (Campbell 1990; Campbell and Griffin 2006), both of which are drastic state interventions aimed at altering the outcomes which would be produced by the market economy. They are both core legal institutions of corporate capitalism that were extremely strongly opposed by supporters of market order, as opposed to corporate capitalism, and, in particular, would be regarded as appalling by Smith. Ex ante regulatory design which facilitated market outcomes would prevent these deplorable features of corporate capitalism and, putting other things aside, have more chance of doing so than ex post attempts to oppose corporate capitalist power based on them. But, of course, one would need to know what one is talking about before one could propose such regulation. 
At root, what is required is the development of self-consciousness of socialism as the necessary basis of welfare enhancing regulation. Without a legal framework which in the end must be based on collective decision making and public law, market order is impossible. The principal task of regulation is not radically moving away from the market but making it clear that the 'private' economic action which is the subject matter of economics - and so economics itself - rests on the social basis of a public regulatory framework (Taylor 1955: 126).

Marx has written some of the most important passages that have ever been written in the history of social theory, and amongst them I would include the following:

The economists [claim that] everyone pursues his private interest and only his private interest, and thereby unintentionally and unwittingly serves the private interests of all, the general interest[. But this] abstract statement could rather lead to the conclusion that everyone mutually hinders the assertion of the interests of everyone else, and instead of a general affirmation, a general negation results from this bellum omnium contra omnes. The point is that the private interest is itself already a socially determined interest, which can be achieved only within the conditions of society and with the means provided by society ... It is the interest of private persons; but its content, as well as the form and means of its realisation, is given by social conditions independent of all (Marx 1857-8/1986-7: vol.28, 93-94).

Marx's critique of capitalism is the most powerful of the criticisms of the alienated belief that the market is directly 'a part of nature and the natural order' of the sort we have seen Sunstein put forward. But even in Marx this led to a disregard of the existential conditions of economic action, which is viewed as an entirely plastic social form, and, leaving aside the terrible historical consequences of seriously implementing policies on this basis, the view of the human condition implied in this disregard is, as Kolakowski (1978: 530) put it, farcical.

In the liberal democracies, it seems politically impossible that regulation could take the literal communist form of subsumption of the general economy to a plan. But this does not mean that left-wing advocacy of social regulation cannot be based on a communist principle, and it normally has been. Social regulation may still be said to be piecemeal only to the very 
limited extent that it is continuously forced to acknowledge, in the existence of an ineliminable freedom of voluntary choice, a refractory way of the world it cannot understand but would do away with if it could. Regulatory support of freedom of choice requires a profound critique of the actually existing capitalist economy's failure to actualise such choice because it does not conform to the conditions of the social market. But all this is neglected in favour of an ever increasing intervention which does not explore or even really accept the fundamentally positive role that the market economy has played and must play.

Capitalism is a social form; but, as Marx, albeit inconsistently and inadequately, acknowledged, it is not only a social form but also, as a mode of production, a form of relationship with nature. Marx never came to terms with the strength of the market as a social form of relationship with nature which is based on individual voluntary choice and therefore on freedom. To draw but one contrast, Simmel's (1892/2011) in other ways far less convincing views are fundamentally stronger on this fundamental issue. Identifying some grave shortcomings of the market economy in the horrors of Victorian capitalism, Marx believed himself to be at liberty to posit a superior alternative which ultimately was based on disregard of the existential constraint of scarcity, and so posited bliss as the ultimate standard for critique of market arrangements, which standard the market indeed does not satisfy. But, though it is essential to criticise the shortcomings of the capitalist market, it is also essential to acknowledge that a failure to satisfy the standard of bliss ultimately is irrelevant because bliss being not vouchsafed to humankind.

In the absence of a positive theory of the market, left-wing regulatory theory, though it can and does justify ever more extensive piecemeal intervention, cannot generally guide welfare improving intervention, much less regulation more widely understood, and, indeed, it is highly arguable that the return to much regulation is now negative. The frustration of all this is so much the greater because, rather than accepting the market on terms now associated 
with neo-liberalism, regulatory theory should stress the socialist truth at the heart of economic action as such. To do this, however, would involve acknowledgement of the existential constraints of humankind's place in nature. The tendency of left-wing regulatory theory has been to do quite the other thing.

\section{Notes}

A reviewer justifiably observed that, if by left wing regulatory theory I meant 'everyone who advocates regulatory interventions into the market', then this would make my use of 'left wing' 'just too easy and glib', not least because it would catch 'an awful lot of people ... including the current government'. As in their brief lives the Governments of Mrs May, despite being handicapped, one would have thought, by consciousness of the limitations of their mandate, have inter alia committed themselves to the complete restructuring of the energy economy, and therefore the entire economy, of the UK, of which the abolition by fiat of the internal combustion engine in cars is but a minor part, I can only agree with the reviewer. That this is not being questioned save in detail, indeed that it is even possible, shows that policies theoretically justified as being piecemeal now routinely embrace every aspect of life in a way that would astonish Pigou, overwhelming evidence of the illegitimate extent of general but inchoate intervention that this paper seeks to criticise. This extension certainly now encompasses the Conservative Party, which is, in this sense, left-wing, and has been since at least Macmillan.

The difference between conservatism which is in this sense left-wing and the leftwing theory I address in this paper is that the latter seeks in principle to put forward a critique of the solipsistic individualism which the former identifies with economic action. 
Remarks which Foucault (1978/2007: 87-114) made in one of his series of Collège de France lectures have generated an approach based on a concept of 'governmentality' which, in its predominant uses at least, extends beyond even the widest sense of regulation to encompass, it seems, all social control of action. As this involves an original focus on the actions of public agencies frequently being wholly relaxed, governmentality need not be discussed here. It must be added, however, that what I understood to be Foucault's account of liberal liberty or freedom as itself merely one form of social control so fundamentally cuts against the political philosophical stance which informs the criticism of statist regulation in this article that dealing with it would be impossible at other than a length necessitating a separate article. On the application of the govenmentality approach to the issues discussed here see Burchell (1991). Hayek's principal works stating his own attempt to identify the principles of 'an evident order that was not the product of a designing human intelligence [but which] need not therefore be ascribed to the design of a higher supernatural order' (Hayek 1960/2011: 115) have recently been most valuably gathered together in a volume (Hayek 2014) of the Collected Works which is in progress. In my opinion, perhaps the most theoretically penetrating account of the law of contract since Macneil, that of Hugh Collins (1999; 2001), has a tendency to prioritise, in the terms used here, social regulation over economic regulation: 'we evaluate the general law of contract as a governance mechanism for steering and controlling markets or private ordering' (Collins 2001: 13). In the space available to me here, it is not possible for me to refine a previous criticism of Collins' approach (Campbell 2000), the gist of which I still think is right, in order to do that approach full justice. For a statement of the general position I wish to criticise by one of the most interesting recent contributors to social theory see Meiksins Wood (1981: 72): 'Marx’s purpose ... 
is to stress not the dualism of the "material" and the "social" but the definition of the material by the social'. See further Meiksins Wood (2017). What I believe to be the fundamentally incorrect stance over the issue of specific concern here, the philosophic anthropology of the economic actor, is expressed in MacPherson's (1962) brilliant account of 'possessive individualism'.

\section{References}

Aalbers MB (2016) Regulated deregulation. In: Springer S et al (eds), The Handbook of Neoliberalism. London: Routledge, pp.563-73.

Ackerman B (1985) Cost benefit and the constitution. In: Noll RG (ed), Regulatory Policy and the Social Sciences. Berkeley CA: University of California Press, pp.351-57. Aglietta M (1976/1979) A Theory of Capitalist Regulation. London: Verso. Althusser, L (1962/1977) Contradiction and overdetermination. In: For Marx. London: New Left Review Editions.

Aslangeigui N and Oakes G (2015) Arthur Cecil Pigou. London: Palgrave Macmillan. Atiyah PS (1979) The Rise and Fall of Freedom of Contract. Oxford: Clarendon Press. Attenborough D (2017) Empirical insights into corporate contractarian theory Legal Studies, $37: 191-213$.

Austin JL (1998) The Province of Jurisprudence Determined. Aldershot: Dartmouth. Ayres I and Brathwaite J (1992) Responsive Regulation. Oxford: Oxford University Press. Bakunin M (1873/1990) Statism and Anarchy. Cambridge: Cambridge University Press. Baldwin R et al (2012) Understanding Regulation, 2nd edn. Oxford: Oxford University Press.

Bardach E and Kagan RA (1982) Going By the Book: The Problem of Regulatory Unreasonableness. Philadephia PA: Temple University Press. 
Barry B (1965/1990) Political Argument. London: Harvester Wheatsheaf.

Bernstein E (1899/1993) The Preconditions of Socialism. Cambridge: Cambridge University Press.

Beveridge W (1936) Prices and planning. In: Planning Under Socialism. London: Longmans and Co, pp.102-108.

Beveridge W (1942) Social Insurance and Allied Services. Cmd. 604.

Braithwaite J (1981-82) The limits of economism in controlling harmful corporate conduct.

Law and Society Review, 16: 481-504.

Braithwaite J (2008) Regulatory Capitalism. Cheltenham: Edward Elgar.

Burchell G (1991) Peculiar interests: Civil society and governing "the system of natural liberty”. In: Foucault M. The Foucault Effect. Chicago IL: University of Chicago Press, pp.119-50.

Campbell D (1990) 'Adam Smith, Farrar on Company Law and the economics of the corporation. Anglo-American Law Review, 19: 185-208.

Campbell D (1999) What is meant by "the rule of law" in Asian company law reform? In:

Tomasic R (ed), Company Law in East Asia. Aldershot: Dartmouth, pp.11-38.

Campbell D (2000) Reflexivity and welfarism in the modern law of contract. Review of H Collins, Regulating Contracts. Oxford Journal of Legal Studies, 20: 477-98.

Campbell D (2002) Bringing law and lawyers to the people: Statism and anarchy in left-wing legal thought. Social and Legal Studies, 11: 413-23.

Campbell D (2003) 'The critique of bourgeois justice after the failure of Marxism. In Kerner et al (eds), Current Legal Issues in the Czech Republic and the United Kingdom, Prague:

Charles University Press, pp.9-25,

Campbell D (2010a) The end of Posnerian law and economics: Review of RA Posner, $A$ Failure of Capitalism. 73 Modern Law Review 73: 302-27. 
Campbell D (2010b) Gathering the water: Abuse of rights after the recognition of government failure. The Journal Jurisprudence, 7: 487-534.

Campbell D (2012) Welfare economics for capitalists: The economic consequences of Judge Posner. Cardozo Law Review, 33: 2233-74.

Campbell D (2016) Ronald Coase's "The Problem of Social Cost". University of Queensland Law Review, 35: 75-98.

Campbell D (2017) The sense in Coase's critique of Pigou. Journal of Law, Economics and Policy, 13: 39-54.

Campbell D (2015) The fetishism of divergence: A critique of Piketty. Journal of Corporate Law Studies, 15: 183-216.

Campbell D (2017) 'Cleverer than command? Review of D Halpern, Inside the Nudge Unit. Social and Legal Studies, 26: 111-26

Campbell D and Griffin S (2006) Enron and the end of corporate governance. In: MacLeod S (ed), Corporate Governance: Global Governance and the Quest for Justice, vol.2. Oxford: Hart, pp.47-72.

Campbell D and Picciotto S (1998) Exploring the interaction between law and economics: The limits of formalism. Legal Studies, 18: 249-78.

Campbell D and Picciotto S (2006) The acceptable face of intervention: Review of W Landes and RA Posner, The Economic Structure of Intellectual Property Law. Social and Legal Studies, 15: 455-72.

Chamberlin EH (1962) The Theory of Monopolistic Competition, 8th edn. Cambridge MA: Harvard University Press.

Coase RH (1960/1986) The problem of social cost. In: The Firm, the Market and the Law. Chicago IL: University of Chicago Press, pp.95-156. 
Coase RH (1974/1994) Economists and public policy. In: Essays on Economics and Economists. Chicago IL: University of Chicago Press, pp.47-63.

Coase RH (1977) Advertising and free speech. Journal of Legal Studies, 6: 1-34.

Collins H (1999) Regulating Contracts. Oxford: Oxford University Press.

Collins H (2001) Regulating contract law. In Parker C et al (eds), Regulating Law, Oxford: Oxford University Press, pp. 13-32.

Crosland CAR (1956) The Future of Socialism. London: Jonathan Cape.

Daintith TC (1979) Regulation by Contract: The new prerogative. Current Legal Problems, 32: 41-64.

Daintith TC (1989) A regulatory space agency. Oxford Journal of Legal Studies, 9: 534-46.

Diamond P (ed), (2014) New Labour's Old Roots. Exeter: Imprint Academic.

Dicey AV (1914/2008) Law and Public Opinion in England During the Nineteenth Century. Indianapolis IN: Liberty Press.

Engels F (1878/1987) Anti-Dühring. In: Marx K and Engels F, Collected Works, vol.25. London: Lawrence and Wishart, pp.1-309.

Engels F (1880/1989) Socialsm: Utopian or Scientific? In: Marx K and Engels F, Collected Works, vol.24. London: Lawrence and Wishart, pp.281-325.

Feingenbaum HB et al (1999) Shrinking the State. Cambridge: Cambridge University Press. Feintuck M (2004) The "Public Interest” in Regulation. Oxford: Oxford University Press. Feintuck M (2010) Regulatory rationales beyond the economic: In search of the public interest. In: Baldwin R et al, The Oxford Handbook of Regulation. Oxford: Oxford University Press, pp.39-63.

Foster CD and Beesley ME (1963/1973) Estimating the Social Benefit of Constructing an Underground Railway in London. In: Beesley, ME, Urban Transport. London, Butterworths, 1973, pp. 1-66. 
Fromm E (1947/2003) Man For Himself. Abingdon: Routledge.

Foucault M (1978/2007) Security, Territory, Population. Basingstoke: Palgrave Macmillan. Fukuyama F (1992) The End of History and the Last Man. London: Penguin.

Gallie WB (1956) Essentially contested concepts. Proceedings of the Aristotelian Society (ns), 56: 167-98.

Giddens A (1998) The Third Way: The Renewal of Social Democracy. Cambridge: Polity Press.

Goodrich P (2009) Law's labour's lost. Modern Law Review, 72: 296-312.

Gray J (1993) The moral foundations of market institutions. In: Beyond the New Right. London: Routledge, pp.66-123.

Hale R (1923) Coercion and Distribution in a Supposedly Non-coercive State. Political Science Quarterly, 38: 470-94.

Halévy É (1901-1904/1959) The Growth of Philosophic Radicalism, corrected edn. London: Faber and Faber.

Hawkins K (2002) Law as Last Resort. Oxford. Oxford University Press.

Hayek FA (1940/1997) Socialist calculation: The “competitive solution”. In: Socialism and War, Collected Works, vol.10. Chicago IL: University of Chicago Press, pp.117-40.

Hayek FA (1944/2007) The Road to Serfdom, Collected Works, vol.2. Chicago IL: University of Chicago Press.

Hayek FA (1960/2011) The Constitution of Liberty. Collected Works, vol.17. Chicago IL: University of Chicago Press.

Hayek FA (1974/2014) The pretence of knowledge. In: The Market and Other Orders, Collected Works, vol.15. London: Routledge, pp.362-72.

Hayek FA (1982) Law, Legislation and Liberty, rev edn. London: Routledge and Kegan Paul. Hayek FA (1988) The Fatal Conceit, Collected Works, vol.1. London: Routledge. 
Hegel, GWF (1807/1977) Phenomenology of Spirit. Oxford: Oxford University Press.

Hicks JR (1941/1981) The rehabilitation of consumer's surplus. In: Wealth and Welfare, Collected Essays in Economic Theory, vol.1. Cambridge MA: Harvard University Press, pp.100-13.

Hood C (1983) The Tools of Government. London: Macmillan.

Horsman M and Marshall A (1994) After the Nation State. London: HarperCollins. Hutt WH (1936/1990) Economists and the Public. New Brunswick NJ: Transaction Publishers.

Jessop B (1978) Capitalism and democracy: The best political shell? In: Littlejohn G et al (eds), Power and the State. London: Croom Helm, pp.10-51.

Kaldor N (1939) Welfare propositions of economics and interpersonal comparisons of utility. Economic Journal, 49: 549-52.

Kant I (1764/2007) Idea for a universal history with a cosmopolitan intent. In: Anthropology, History and Education. Cambridge: Cambridge University Press.

Kapp KW (1950/1978) The Social Costs of Business Enterprise. London: Spokesman Books. Keynes JM (1934/2013) Mr Keynes replies to Shaw. In: Collected Writings, vol.28.

Cambridge: Cambridge University Press, pp.30-35.

Keynes JM (1936/1973) The General Theory of Employment, Interest and Money. In: Collected Writings, vol.7. London: Macmillan.

Kolakowski L (1978) The Main Currents of Marxism, vol.3. Oxford: Clarendon Press. Kornai J (1992) The Socialist System. Oxford: Clarendon Press. Kumekawa I (2017) The First Serious Optimist: A C Pigou and the Birth of Welfare Economics. Princeton NJ: Princeton University Press.

Lipsey RG and Lancaster K (1956). The general theory of second best. Review of Economic Studies, 24: 11-32. 
Lasch C (1991) The True and Only Heaven. New York NY: Norton.

Le Grand J and Bartlett W (eds), (1993) Quasi-markets and Social Policy. Houndmills:

Macmillan.

Levi-Faur D (2013) The odyssey of the regulatory state: From a "thin" monomorphic concept to a "thick" and polymorphic concept. Law and Policy, 35: 29-50.

Levi-Faur D (2017) Regulatory capitalism. In: Drahos P (ed), Regulatory Theory. Canberra: Australian National University Press, pp.289-302.

Lippmann W (1937/2005) The Good Society. New Brunswick NJ: Transaction Publishers.

Luhmann N (1995) Social Systems. Stanford CA: Stanford University Press.

MacIntyre A (1985) After Virtue, 2nd edn. London: Duckworth.

Macpherson CB (1962) The Political Theory of Possessive Individualism. Oxford: Oxford University Press.

Majone G (1994) The rise of the regulatory state in Europe. West European Politics, 17: 77101.

Majone G (1996) Regulating Europe. London: Routledge.

Majone G (ed), (1992) Deregulation or Reregulation? London: Cengage Learning.

Malle S (1985) The Economic Organisation of War Communism 1918-23. Cambridge:

Cambridge University Press.

Mandelson P (2002) The Blair Revolution Revisited. London: Politico's.

Mandelson P and Liddle R (1996) The Blair Revolution. London: Faber.

Marquand D (2015) Mammon's Kingdom, pbk edn. London: Penguin.

Marx K (1850/1978) The Class Struggles in France. In: Marx K and Engels F, Collected

Works, vol.10. London: Lawrence and Wishart, pp.45-239.

Marx K (1857-8/1986-7) 'Economic manuscripts of 1857-8 [the Grundrisse]'. In Marx K and Engels F, Collected Works, vol.28 and vol.29, pp.1-256. London: Lawrence and Wishart. 
Marx K (1859/1987) A Contribution to the Critique of Political Economy. In: Marx K and Engels F, Collected Works, vol.29, pp.257-417.

Marx, K (1867/1996) Capital, vol.1. In: Marx K and Engels F, Collected Works, vol.35. New York NY: International Publishers.

Marx K (1871/1986) The Civil War in France. In: Marx K and Engels F, Collected Works, vol.22. London: Lawrence and Wishart, pp. 307-59.

Marx, K (1875/1989) Critique of the Gotha Programme. In: Marx K and Engels F, Collected Works, vol. 24. London: Lawrence and Wishart, pp.75-99.

Marx, K (1885/1997) Capital, vol.2. In: Marx K and Engels F, Collected Works, vol.36. New York NY: International Publishers.

Marx, K (1894/1998) Capital, vol.3. In: Marx K and Engels F, Collected Works, vol.37. New York NY: International Publishers.

Marx K and Engels F (1845/1976) The German Ideology. In: Marx K and Engels F, Collected Works, vol.5. London: Lawrence and Wishart, pp.19-539.

Marx K and Engels F (1848/1976) Manifesto of the Communist Party. In: Marx K and Engels F, Collected Works, vol.6. London: Lawrence and Wishart, pp. 477-519.

Mason P (2016) Postcapitalism. London: Penguin.

Miliband R (1969/1973) The State in Capitalist Society. London: Quartet Books. Miliband R (1983/2015) State power and class interests. In: Class War Conservatism and Other Essays. London: Verso, pp. 63-78.

Minogue K (1978) On hyperactivism in modern British politics. In Cowling M (ed), Conservative Essays. London: Cassell, pp.117-30.

Monsen RJ and Downs A (1971) Public goods and private status. National Affairs, 23: 64-77. 
Müller E and Neusüss C (1970/1978) The "welfare state illusion" and the contradiction between wage-labour and capital. In: Holloway J and Picciotto S (eds), State and Capital. London: Edward Arnold.

Moran M (2003) The British Regulatory State. Oxford: Oxford University Press.

Nove A (1982) An Economic History of the USSR, rev edn. Harmondsworth: Penguin.

Nove A (1983) The Economics of Feasible Socialism. London: George Allen and Unwin.

Nozick R (1974) Anarchy, State and Utopia. New York NY: Basic Books.

Off C (1984) Contradictions of the Welfare State. London: Hutchinson.

Ogus A (1992) Regulatory law: Some lessons from the past. Legal Studies, 12: 1-19.

Ogus A (1994) Regulation. Oxford: Clarendon Press.

Ogus A (2006) Costs and Cautionary Tales. Oxford: Hart.

(Orwell G (1944/2001) Review of The Road to Serfdom by FA Hayek and The Mirror of the

Past by K Zilliacus. In: I Have Tried to Tell the Truth: Complete Works, vol.16, rev edn.

London: Secker and Warburg, pp.149-50.

Orwell G (1946/2001) The Intellectual Revolt. In: Smothered Under Journalism: Complete

Works vol.18, rev edn. London: Secker and Warburg, pp.56-59.

Osborne D and Gaebler T (1992) Reinventing Government: How the Entrepreneurial Spirit is Transforming the Public Sector. Reading MA: Addison-Wesley.

Parsons T (1968) The Structure of Social Action, pbk edn. New York NY: Free Press.

Picciotto S (2011) Regulating Global Corporate Capitalism. Cambridge: Cambridge University Press.

Pigou AC (1920/2002) The Economics of Welfare. New Brunswick NJ: Transaction Books.

Pigou AC (1937) Socialism Versus Capitalism. London: Macmillan.

Piketty T (2014) Capital in the Twenty-first Century. Cambridge MA: Belknap Press.

Plant R (2010) The Neo-liberal State. Oxford: Oxford University Press. 
Popper KR (1966) The Open Society and Its Enemies, vol.1, 5th edn. London: Routledge and Kegan Paul.

Prosser T (2010) The Regulatory Enterprise. Oxford: Oxford University Press.

Raz J (1986) The Morality of Freedom. Oxford: Clarendon Press.

Reisman DA (1997a) Anthony Crosland: The Mixed Economy. Basingstoke: Macmillan.

Reisman DA (1997b) Crosland's Future. Basingstoke: Macmillan.

Robbins L (1935) The Nature and Significance of Economic Science, 2nd edn. London:

Macmillan.

Scharpf F (1999). Governing in Europe: Effective and Democratic? Oxford: Oxford

University Press.

Schmidt A (1962/1971) The Concept of Nature in Marx. London: New Left Books.

Scott C (2010) Regulatory governance and the challenge of constitutionalism. In: Prosser T et al (eds), The Regulatory State. Oxford: Oxford University Press.

Seidman H and Gilmour R (1986), Politics, Position and Power: From the Positive to the Regulatory State, 4th edn. New York NY: Oxford University Press.

Selznick P (1985) Focusing organisational research on regulation. In: Noll RG (ed), Regulatory Policy and the Social Sciences. Berkeley CA: University of California Press, pp.363-67.

Simmel G (1892/2011) The Philosophy of Money. London: Routledge.

Smith A (1759/1976) The Theory of Moral Sentiments. In: The Glasgow Edition of the Works and Correspondence, vol.1. Oxford: Clarendon Press.

Smith A (1762-66/1978) Lectures on Jurisprudence. In: The Glasgow Edition of the Works and Correspondence, vol.5. Oxford: Clarendon Press.

Smith A (1776/1976) The Wealth of Nations. In: The Glasgow Edition of the Works and Correspondence, vol.2. Oxford: Clarendon Press. 
Stewart D (1794/1980) Account of the Life and Writings of Adam Smith LLD. In: Smith A, Essays on Philosophical Subjects, The Glasgow Edition of the Works and Correspondence, vol.3. Oxford: Clarendon Press, pp.264-351.

Stigler GJ (1975) The Citizen and the State. Chicago IL: University of Chicago Press. Sunstein CR (1990) After the Rights Revolution: Reconceiving the Regulatory State. Cambridge MA: Harvard University Press.

Sunstein CR (1997) Free Markets and Social Justice. Oxford: Oxford University Press. Sunstein CR (2016) The Ethics of Influence. Cambridge: Cambridge University Press. Tawney RH (1935/1981) Christianity and the social revolution. In: The Attack. London: Spokesman Books, pp.157-66.

Taylor AJ (1972) Laissez-faire and State Intervention in Nineteenth Century Britain. London: Macmillan.

Taylor OH (1955) Non-economic elements in social life. In Economics and Liberalism, Cambridge MA: Harvard University Press, pp.117-???.

Thaler RH and Sunstein CR (2003) Libertarian paternalism. American Economic Review, 93(2): $175-79$.

Thaler RH and Sunstein CR (2009) Nudge, rev edn. London: Penguin. Tshuma L (1999) The political economy of the World Bank's Legal Framework for development. Social and Legal Studies, 8(1): 75-96.

Vincent-Jones P (2006) The New Public Contracting. Oxford: Oxford University Press. Vogel SK (1996) Freer Markets: More Rules. Ithaca (USA): Cornell University Press. Walicki A (1995) Marxism and the Leap to the Kingdom of Freedom. Stanford CA: Stanford University Press.

Weale A (1985) Toleration, individual differences and respect for persons. In: Horton JP and Mendus S (eds), Aspects of Toleration. London: Methuen, pp.16-35. 
Weber M (1922/1978) Economy and Society. Berkeley CA: University of California Press.

Whitehead AN (1926) Science and the Modern World. Cambridge: Cambridge University Press.

Wilson E (1940) To the Finland Station. Garden City NY: Doubleday.

Meiksins Wood E (1981) The separation of the economic and the political in capitalism. New Left Review, I/127: 66-95.

Meiksins Wood E (2017) The Origins of Capitalism: A Longer View. London: Verso. 